\title{
THE OCCURRENCE OF THE MARKERS OF HEPATITIS C AMONG PRACTICALLY HEALTHY RESIDENTS OF THE REPUBLIC OF GUINEA: A PILOT STUDY
}

\author{
O.V. Kalinina ${ }^{a}$, E.V. Lichnaia ${ }^{a}$, M.Y. Boiro ${ }^{b}$, Areg A. Totolian ${ }^{a}$ \\ ${ }^{a}$ St. Petersburg Pasteur Institute, St. Petersburg, Russian Federation \\ ${ }^{b}$ Institute of Applied Biology in Guinea, Kindia, Republic of Guinea
}

\begin{abstract}
Phylogeographical and philodinamic studies have shown that the hepatitis $\mathrm{C}$ virus began to circulate in the human population about 500-2000 years ago on the African continent and only in the $20^{\text {th }}$ century, this virus received the ubiquitary distribution. According to WHO in the world more than 71 million people are chronically infected by the hepatitis $\mathrm{C}$ virus, more than half of them live in Africa and South-East Asia. At the same time, the actual prevalence of hepatitis $C$ in most countries of sub-Saharan Africa, including the Republic of Guinea, remains poorly understood. The aim of this study was to evaluate the occurrence of serological and molecular markers of hepatitis $\mathrm{C}$ on a random small selection of blood samples obtained from healthy adults of the Republic of Guinea. Materials and methods. Serum and plasma blood samples obtained from thirty one healthy adults of 24-71 years old of the Republic of Guinea were examined. Blood samples were collected in 2015-2016 years. The serum samples were analyzed for the presence of total anti-HCV $(\operatorname{IgG}+\operatorname{IgM})$, of specific antibodies to the core, the NS3, the NS4 and the NS5B HCV proteins, of core antigene with "DS-ELISA-ANTI-HCV-GM", "DS-ELISA-ANTI-HCV-SPEKTRE-GM", "DS-ELISA-HCV-Ag" detection kits (RPC "Diagnostic Systems", Russia), respectively. RNA HCV were detected by RT-PCR with detection kit "AmpliSens HCV-FRT" (CRIE, Moscow) and by nested-PCR using the primers from 5'UTR region. HCV genotypes were determined by RT-PCR with detection kit "AmpliSens HCV-genotype FRT" (CRIE, Moscow) and by phylogenetic analysis based on the 5'UTR region. Results and discussion. In this pilot study, the presence of $\mathrm{HCV}$ markers was confirmed in 3 (9.68\%, 95\% CI 3.35-24.90) of 31 examined persons. Two of them had RNA HCV. Based on the phylogenetic analysis of the 5'UTR region of the HCV genome, the isolate obtained from person No. 5 belonged to genotype 1, and the isolate obtained from person No. 6 belonged to genotype 2. The obtained results together with the analyzed literature data indicate a significant burden of hepatitis $\mathrm{C}$ in the Republic of Guinea, and also indicate the need to develop both an algorithm of diagnostic criteria and the improvement of diagnostic test systems for mass screening of the African population in order to establish the proportion of persons involved in epidemic process.
\end{abstract}

Key words: hepatitis C virus, Republic of Guinea, serological markers, molecular markers, genotype, diagnostic test systems.

\author{
Адрес для переписки: \\ Калинина Ольга Викторовна \\ 197101, Россия, Санкт-Петербург, ул. Мира, 14, \\ ФБУН НИИЭМ имени Пастера. \\ Тел.: 8 (812) 233-29-41 (служебн.); +7 921 746-39-07 (моб.). \\ E-mail: olgakalinina@mail.ru
}

\section{Contacts:}

Olga V. Kalinina

197101, Russian Federation, St. Petersburg, Mira str., 14,

St. Petersburg Pasteur Institute.

Phone: +7 (812) 233-29-41 (office); +7 921 746-39-07 (mobile). E-mail: olgakalinina@mail.ru

\section{Citation:}

Kalinina O.V., Lichnaia E.V., Boiro M.Y., Totolian Areg A. The occurrence of the markers of hepatitis $\mathrm{C}$ among practically healthy residents of the Republic of Guinea: a pilot study // Russian Journal of Infection and Immunity = Infektsiya i immunitet, 2017, vol. 7, no. 3, pp. 245-250. doi: 10.15789/22207619-2017-3-245-250 


\title{
ВСТРЕЧАЕМОСТЬ МАРКЕРОВ ВИРУСА ГЕПАТИТА С У ПРАКТИЧЕСКИ ЗДОРОВЫХ ЖИТЕЛЕЙ ГВИНЕЙСКОЙ РЕСПУБЛИКИ: ПИЛОТНОЕ ИССЛЕДОВАНИЕ
}

\author{
О.В. Калинина ${ }^{1}$, Е.В. Личная ${ }^{1}$, М.Й. Буаро르, Арег А. Тотолян ${ }^{1}$ \\ ${ }^{1}$ ФБУН НИИ эпидемиологии и микробиологии имени Пастера, Санкт-Петербург, Россия \\ ${ }^{2}$ НИИ прикладной биологии Гвинеи, г. Кинди, Гвинейская Республика
}

Резюме. Филогеографические и филодинамические исследования показали, что вирус гепатита С начал циркулировать в человеческой популяции около 500-2000 лет тому назад на африканском континенте, но лишь в XX веке получил убиквитарное распространение. Согласно расчетным данным ВО3 на 2017 г. в мире более 71 млн человек хронически инфицировано вирусом гепатита С, более половины из которых проживает на территории Африки и Юго-Восточной Азии. При этом до сих пор фактическая распространенность вируса гепатита С в большинстве стран Африки южнее Сахары, в том числе в Гвинейской Республике, остается малоизученной. Цель исследования: оценить встречаемость серологических и молекулярных маркеров гепатита С на случайной малой выборке образцов крови, полученных от практически здоровых жителей Гвинейской Республики. Материалы и методы. Изучены образцы сыворотки и плазмы крови, полученные в 2015-2016 гг. от 31 практически здорового жителя Гвинейской Республики в возрасте от 24 до 71 года. Наличие суммарных анти-HCV (IgG+IgM), специфических антител к core, NS3, NS4 и NS5 белкам, свободного core антигена определяли методом ИФА с использованием тест-систем «ДС-ИФААНТИ-НСV», «ДС-ИФА-АНТИ-НСV-CПЕКТР-GM», «ДС-ИФА-HCV-АГ» (ООО «Диагностические системы», Россия) соответственно. Детекцию РНК ВГС проводили двумя методами: ПЦР в режиме реального времени с использованием тест-системы «АмплиСенс HCV-FL» (ФБУН ЦНИИЭ, Россия) и методом гнездной ПЦР с праймерами из 5'UTR области генома. Генотипы изолятов ВГС определяли методом ОТ-ПЦР в режиме реального времени с использованием «АмплиСенс HCV-генотип-FL» вариант 1-6, определяющей генотипы 1a, 1b, 2, 3a, 4, 5a, 6 (ФБУН ЦНИИЭ, Россия), а также на основе филогенетического анализа нуклеотидных последовательностей из 5'UTR области генома. Результаты и обсуждение. В данном пилотном исследовании наличие маркеров ВГС подтверждено у 3 (9,68\%, 95\% CI 3,35-24,90) из 31 обследованного. У двух из них обнаружена РНК ВГС. На основе филогенетического анализа 5'UTR области генома изолят, полученный от пациента № 5, принадлежал к генотипу 1, а изолят, полученный от пациента № 6, - к генотипу 2. Полученные результаты в совокупности с проанализированными литературными данными свидетельствуют о существенном бремени гепатита С в Гвинейской Республике, а также указывают на необходимость разработки как алгоритма диагностических критериев, так и совершенствования диагностических тест-систем для проведения массового скрининга африканского населения с целью установления доли вовлеченных в эпидемический процесс лиц.

Ключевые слова: вирус гепатита С, Гвинейская Республика, серологические маркеры, молекулярные маркеры, генотип, диагностические тест-системы.

\section{Introduction}

According to the World Health Organization, more than 71 million people globally are chronically infected with the hepatitis C virus (HCV), about 399 thousand people die of liver diseases associated with hepatitis C (HC) every year [17]. Hepatitis C virus is one of the most dynamically evolving pathogens, which makes it difficult to develop effective immunoprophylactic vaccines and allows the virus to successfully adapt to the effects of immune defense factors of the human body, contributing to a significant incidence of the disease chronicity.

Despite the significant genetic variability of $\mathrm{HCV}$, only 6 subtypes (1a, 1b, 2a, 2b, 2c, 3a) are recognized as epidemic variants, which provided the ubiquitous propagation of the pathogen during the 20th century [1]. The remaining HCV subtypes are characterized by local geographical ranges, mainly in Africa and South-East Asia, where, as a rule, none of the six epidemic variants of the virus are dominant.
The overall HCV infection of the population of the Sub-Saharan Africa is high [10]. A wide range of HCV variants have been found in Africa: genotypes 1 and 4 in Central Africa; genotypes 2 and 4 in North Africa; and genotype 2 in West Africa and Cameroon $[1,2,8,9,12,14]$. The study of the $\mathrm{HC}$ virus evolution indicates that most of its subtypes occurred more than 300 years ago on the African continent, which is now considered a potential pool of "future" epidemic variants of HCV. At the same time, due to economic and social reasons, the prevalence and genetic diversity of $\mathrm{HCV}$, the route of the pathogen transmission, as well as the clinical course of the infection in many countries of sub-Saharan Africa, including the Republic of Guinea, still remain understudied.

The aim of the study was to evaluate the occurrence of serological and molecular markers of hepatitis $\mathrm{C}$ on a random small batch of blood samples obtained from practically healthy residents of the Republic of Guinea. 


\section{Materials and Methods}

The work studies samples of blood serum and plasma, obtained in 2015-2016 from 31 practically healthy inhabitants of the Republic of Guinea at the age from 24 to 71 years. All samples of serum and plasma were obtained for scientific research under the code names according to the Declaration of Helsinki under the protocol of the Ethics Committee of the SaintPetersburg Pasteur Institute. After taking the biomaterial, all samples were aliquoted and stored at $-70^{\circ} \mathrm{C}$ until the study was performed.

The presence of total antibodies to the hepatitis $\mathrm{C}$ virus (anti-HCV IgG $+\mathrm{IgM}$ ) was determined using the DS-EIA-ANTI-HCV (RPC "Diagnostic Systems", Russia), and having international certificates of $\mathrm{CE}$ products. The samples that revealed reactivity for the presence of total anti-HCV were retested in duplicate using the same method. The presence of specific antibodies $(\operatorname{IgG}+\operatorname{IgM})$ to the structural (core) and nonstructural (NS3, NS4, NS5) proteins of the hepatitis $\mathrm{C}$ virus (HCV) was confirmed using the DSEIA-ANTI-HCV-SPECTRUM-GM test system (RPC "Diagnostic Systems", Russia). The presence of free core $\mathrm{HCV}$ antigen (Ag core) was assessed by EIA method using the DS-EIA-HCV-AG test system (RPC "Diagnostic Systems", Russia), which is designed to detect the core HCV antigen in the absence of anti-HCV in blood plasma and serum samples.

Total RNA was released from $100 \mu 1$ of blood plasma/serum sample using the "AmpliPrime RiboSorb" and "AmpliPrime Ribo-Prep" commercial kits (CRIE, Moscow) according to the manufacturer's instructions. Total RNA was stored at $-70^{\circ} \mathrm{C}$. The reverse transcription reaction was performed using the "Reverta L" commercial kit (CRIE, Moscow) according to the manufacturer's instructions, or using 100 units of MMLV reverse transcriptase enzyme (Eurogen, Russia) and $20 \mu \mathrm{M}$ of random primers in $20 \mu \mathrm{l}$ of reaction mixture containing $10 \mathrm{mM}$ of each of the nucleoside triphosphates (dNTP), $10 \mathrm{mM}$ of DTT, and 10 units of Rnazin. The reverse transcription reaction was performed during 1 hour at $42^{\circ} \mathrm{C}$.

The study of the biological material for the presence of HCV RNA was carried out by two methods: by realtime PCR method using the "AmpliSens HCV-FL" commercial test system (CRIE, Moscow), according to the instructions, in the Rotor-Gene 6000 amplifier (Corbett Research, Australia), and by nested PCR method with primers from the most conserved region of the 5'UTR genome as described previously [7]. The products of nested PCR were visualized in $2 \%$ agarose gel with the addition of ethidium bromide in ultraviolet light. The fragment size after the second stage of PCR with internal primers from the 5'UTR region made up 235 base pairs (bp).

The genotypes of HCV isolates were determined by real-time RT-PCR using the commercial "AmpliSens HCV-Genotype-FL" ver. 1-6 test system, which determines the 1a, 1b, 2, 3a, 4, 5a, 6 genotypes (CRIE, Moscow), as well as by method of phylogenic analysis of nucleotide sequences from the 5'UTR region of the genome. In the latter case, the products obtained as a result of nested PCR were purified using the AxyPrep PCR Clean-up Kit commercial panel (Axygen, Biosciences). The limited sequencing reaction was performed using BigDye Terminator Cycle Sequencing Ready Kits (PE Biosystems, ver. 3.1) and 4 pmol of the corresponding primer. The capillary electrophoresis was performed on the ABI PRISM 3500 automatic sequencer (Applied Biosystems, USA). The analysis of nucleotide sequences was performed using the Mega ver. 6.0 software. The phylogenetic analysis was performed by the Maximum Likelihood method in the Mega ver. 6.0 software. For the genotyping of isolates obtained from the residents of the Republic of Guinea, a sample of reference nucleotide sequences of $\mathrm{HCV}$ isolates was generated using the BLAST on-line software, including all sequences from the 5'UTR region of the genome of isolates obtained from the residents of the Republic of Guinea and recorded in GenBank.

The obtained data were processed by standard methods of statistical processing of digital material: the confidence limits $(95 \% \mathrm{CI}$ ) were calculated using the Wilson method.

\section{Results and Discussion}

Of the 31 persons examined using the "DS-EIAANTI-HCV" test system, six persons were revealed to have positive results for the presence of anti-HCV in their blood serum samples, while the remaining 25 examined persons had anti-HCV negative samples. No free core antigen was detected in any blood serum sample using the "DS-EIA-HCV-AG" test system.

The presence of specific antibodies to several $\mathrm{HCV}$ proteins was found in five of six anti-HCV positive samples using the "DS-EIA-ANTI-HCVSPECTRUM-GM" confirmatory test (Table). In this case, antibodies to the core protein with a high cutoff index (COI) greater than 8 were found only in two samples (No. 5 and No. 6). Antibodies to all the four $\mathrm{HCV}$ core, NS3, NS4 and NS5 proteins were detected in one sample (No. 4). However, the antibodies to the core protein in this sample had COI less than 2.0. At the same time, antibodies to the NS3 protein with COI greater than 10 and antibodies to the NS4 protein with COI less than 2.0 were detected in the sample No. 3. Antibodies to NS3 and NS5 proteins with average COI were detected in the sample No. 1. Antibodies only to the NS3 protein were detected in the sample No. 2. In our opinion, the presence of basically antibodies to the NS3 protein in samples No. 1, 2 and 3, as well as the absence of antibodies to the core protein, may indicate the presence of false-positive results of serodiagnosis. 
Table. The results of HCV markers detection in blood serum/plasma samples obtained from practically healthy residents of the Republic of Guinea

\begin{tabular}{|c|c|c|c|c|c|c|}
\hline Patient No. & Anti-HCV (COI ${ }^{*}$ ) & Anti-core (COI) & Anti-NS3 (COI) & Anti-NS4 (COI) & Anti-NS5 (COI) & HCV RNA \\
\hline 1 & $+(5.0)$ & - & $+(5.69)$ & - & $+(2.94)$ & - \\
\hline 2 & $+(4.03)$ & - & $+(6.33)$ & - & - & - \\
\hline 3 & $+(12.68)$ & - & $+(10.73)$ & $\pm(1.46)$ & - & - \\
\hline 4 & $+(5.42)$ & $\pm(1.21)$ & $+(5.27)$ & $+(4.83)$ & $+(2.53)$ & - \\
\hline 5 & $+(9.87)$ & $+(8.0)$ & $\pm(1.13)$ & - & - & + \\
\hline 6 & $+(16.4)$ & $+(8.83)$ & $\pm(1.18)$ & $+(3.06)$ & - & + \\
\hline
\end{tabular}

Notes. ${ }^{*} \mathrm{COI}$ (cutoff index) $=\mathrm{OD}$ of the sample/critical OD; " \pm " the result is equivocal, "+" the result is positive, "-" the result is negative.

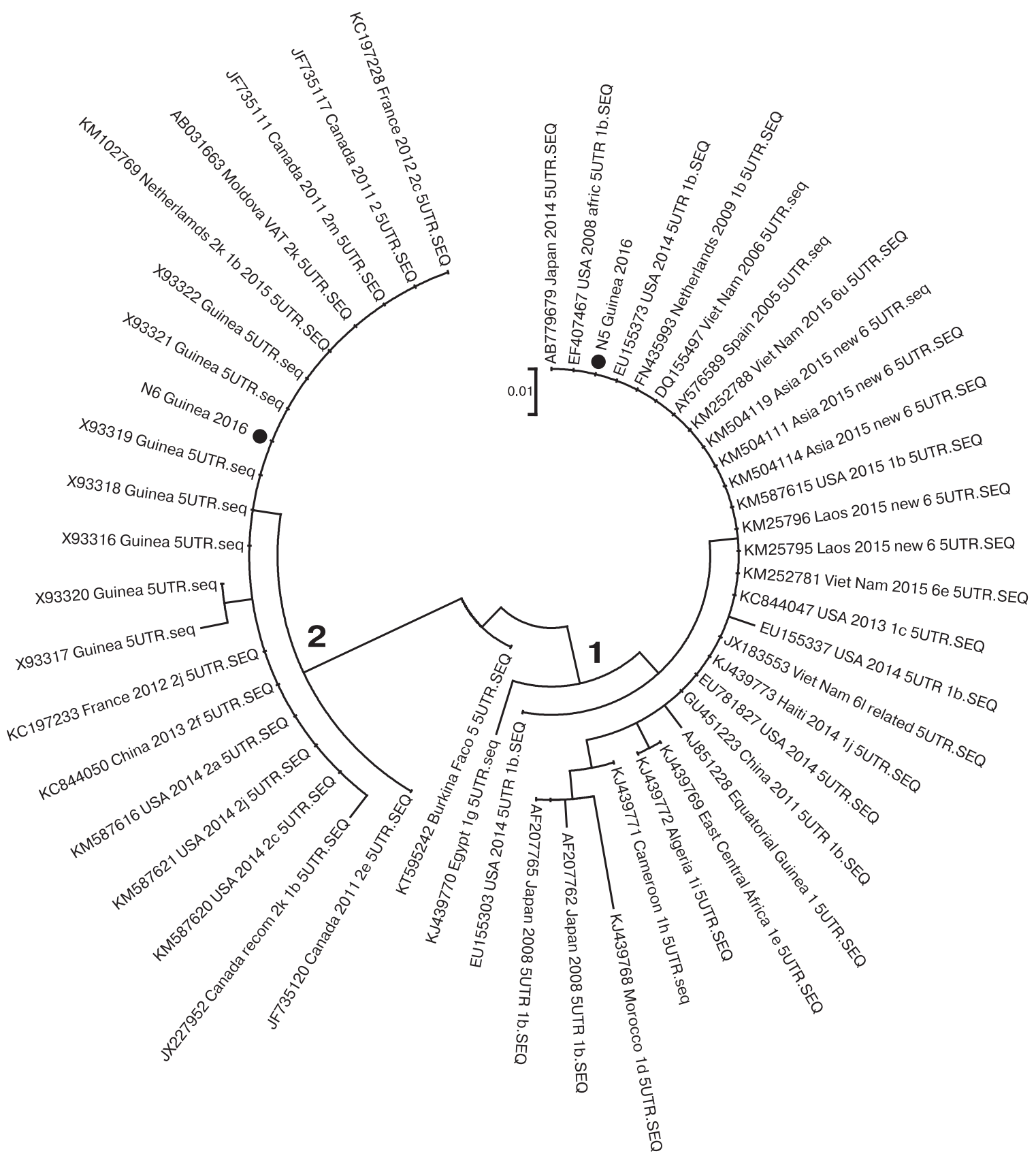

Figure. The phylogenetic tree based on 165 base nucleotides from the 5'UTR region of the HCV genome using the Maximum Likelihood method in the Mega 6.0 software

Notes. Guinean isolates obtained in 2016 are marked with a black circle. Figures indicate the branches formed by HCV isolates of genotypes 1 and 2 . 
The presence of a large number of false-positive results of HCV serodiagnosis is an actual problem on the African continent, as noted in a number of studies [11, 16]. For example, in the study of 1000 samples of blood serum obtained from residents of Rakaya (Uganda), the presence of anti-HCV was detected in $7.6 \%$ of samples using the Ortho ver. 3.0 commercial test system (Ortho Clinical Diagnostics, Denmark). At the same time, HCV RNA was not detected in any of the anti-HCV positive samples using the Abbott RealTime HCV Assay commercial test system (Abbott Molecular Inc.) [11]. The work makes the assumption of the probability of false-positive results due to a possible cross-reaction associated with the Schistosoma mansoni infection, which is widespread on the African continent. In favor of a large number of false-positive results, this study also showed no evidence of liver fibrosis in all anti-HCV positive patients [11]. In the study by Tagny et al. (2014) among 1998 blood samples obtained from blood donors in Cameroon, 86 samples $(4.3 \%)$ were revealed to be anti-HCV positive using the HCV Rapid Test (Human Diagnostics, Germany) and/or Monolisa HCV Ag/Ab Ultra (BioRad, France). Of the 86 anti$\mathrm{HCV}$ positive samples, only 37 were confirmed as positive, 29 as negative and 20 samples remained equivocal using HCV Immunoblot RIBA3 (Ortho Clinical Diagnostica, France) confirmatory test and/or TaqMan HCV (Roch Molecular Diagnostics, France, limit 25 copies/ml) [16].

In our study, HCV RNA was revealed in one of 31 patients examined by real-time RT-PCR using the "AmpliSens HCV-FL" commercial test system. However, we failed to establish the genotype using the "AmpliSens HCV-Genotype-FL" test system. At the same time, HCV RNA was detected in two (No. 5 and No. 6) of the 31 patients examined by nested PCR method with specific primers from the 5'UTR region. The nucleotide sequence for both $\mathrm{HCV}$ isolates was determined. Based on the phylogenic analysis of the 5'UTR region of the genome, the isolate obtained from the patient No. 5 belonged to the genotype 1, and the isolate obtained from the patient No. 6 belonged to the genotype 2 (Fig.).

Thus, the combination of data in this study confirmed the presence of $\mathrm{HCV}$ markers in $3(9.68 \%$, 95\% CI 3.35-24.90) of the 31 examined patients. The results obtained for other three patients require further observation and specification.

According to previous studies, HCV seroprevalence in the Republic of Guinea ranges from $2.6 \%$ in pregnant women to $15 \%$ among people at risk patients with chronic kidney diseases. For example, in a survey carried out in 1996, anti-HCV was detected in $6.7 \%$ of 1421 examined patients aged 16 to 45 years (blood donors, pregnant women, patients from polyclinics and clinics) in the city of Conakry [15]. Among patients from polyclinics and clinics in Conakry, the infection was as high as $8.6 \%$, among blood donors it was $4.4 \%$, and the lowest prevalence of $2.6 \%$ was detected among pregnant women [15]. Of the 579 patients with chronic kidney diseases monitored during 2009-2013 in the only nephrological center of the Republic of Guinea, $15 \%$ had anti$\mathrm{HCV}$ [3].

The available data on the HCV seroprevalence in African countries indicate quite pronounced territorial differences in the intensity of the epidemic process in different regions of the whole African continent and within individual countries, which is connected, inter alia, with national traditions characteristic of certain ethnic groups. For example, the prevalence of $\mathrm{HCV}$ markers in various regions of Nigeria ranges from $1.9 \%$ among pregnant women in Benin to $15 \%$ in isolated rural communes [5, 13]. According to the meta-analysis by Gower et al. (2014), HCV seroprevalence in West Africa averages 5.3\% $(95 \%$, CI 2.9-9.1), in Central Africa - 4.2\% (95\%, CI 2.49.2), in East Africa - 1.0\% (95\%, CI 0.6-3.1) and in South Africa $-1.3 \%$ (95\%, CI 0.8-2.5) [6]. In the study by Mora et al. (2016) based on the analysis of data reported for 2000-2013, HCV seroprevalence averages $4.14 \%$ (95\% CI 3.25-5.20) in West African countries; $7.82 \%$ (95\% CI 5.29-11.43) in Central African countries; $3 \%$ (95\% CI 2.23-4.02) in the countries of East Africa; and 0,72\% (95\% CI 0.33$1.54)$ in the countries of South Africa [10]. In general, due to the absence of mass screening and recording of viral hepatitis $\mathrm{C}$ cases in developing countries, it is difficult to estimate the dynamics of the epidemic process, and the actual spread of HCV in sub-Saharan Africa in modern conditions of active population migration may be higher than the estimated average. This is supported by the data obtained in the examination of 14205 African immigrants aged 15 to 58 years in the 2013-2015 period in official national camps organized in Libya [4]. The HCV seroprevalence averaged $8.1 \%$ among 4,993 immigrants from West Africa, 5.7\% among 2557 immigrants from Central Africa, 8.4\% among 3524 immigrants from East Africa, and 10.0\% among 3131 immigrants from North Africa [4].

\section{Conclusion}

Despite a small sample batch, the results obtained in conjunction with the analyzed reported data indicate a significant burden of hepatitis $\mathrm{C}$ in the Republic of Guinea, and also point to the need both to develop an algorithm of diagnostic criteria and to improve the diagnostic test systems for mass screening among the African population with a view to establishing the proportion of people involved in the epidemic process. Undoubtedly, a large-scale comprehensive screening study will allow to assess the actual HCV prevalence among various groups of population in the Republic of Guinea. 


\section{References}

1. ебрун А.Б., Калинина О.В. Вирусный гепатит С: эволюция эпидемического процесса, эволюция вируса // Журнал микробиологии, эпидемиологии и иммунобиологии. 2016. № 1. С. 102-112. [Zhebrun A.B., Kalinina O.V. Viral hepatitis C: evolution of the epidemiologic process, evolution of the virus. Zhurnal mikrobiologii, epidemiologii $i$ immunobiologii $=$ Journal of Microbiology, Epidemiology and Immunobiology, 2016, no. 1, pp. 102-112. (In Russ.)]

2. Калинина О.В. Вирус гепатита С: механизмы изменчивости, классификация, эволюция // Вопросы вирусологии. 2015. T. 60, № 5. C. 5-10. [Kalinina O.V. Hepatitis C virus: variability mechanisms, classification, evolution. Voprosy virusologii $=$ Problems of Virology, 2015, vol. 60, no. 5, pp. 5-10. (In Russ.)]

3. Bah A.O., Lamine C., Balde M.C., Bah M.L., Rostaing L. Epidemiology of chronic kidney diseases in the Republic of Guinea; future dialysis needs. J. Nephropathol., 2015, vol. 4, no. 4, pp. 127-133. doi: 10.12860/jnp.2015.24

4. Daw M.A., El-Bouzedi A., Ahmed M.O., Dau A.A, Agnan M.M. In association with the Libyan Study Group of Hepatitis \& HIV. Epidemiology of hepatitis $C$ virus and genotype distribution in immigrants crossing to Europe from North and sub-Saharan Africa. Travel Med. Infect. Dis., 2016, vol. 14, no. 5, pp. 517-526. doi: 10.1016/j.tmaid.2016.05.020

5. Forbi J.C., Purdy M.A., Campo D.S., Vaughan G., Dimitrova Z.E., Ganova-Raeva L.M., Xia G.L., Khudyakov Y.E. Epidemic history of hepatitis C virus infection in two remote communities in Nigeria, West Africa. J. Gen. Virol., 2012, vol. 93, pt. 7, pp. 1410-1421. doi: 10.1099/vir.0.042184-0

6. Gower E., Estes C., Blach S., Razavi-Shearer K., Razavi H. Global epidemiology and genotype distribution of the hepatitis $\mathrm{C}$ virus infection. J. Hepatol., 2014, vol. 1, suppl. 1, pp. S45-S57. doi: 10.1016/j.jhep.2014.07.027

7. Kalinina O., Norder H., Vetrov T., Zhdanov K., Barzunova M., Plotnikova V., Mukomolov S., Magnius L. Shift in predominating subtype of HCV from $1 \mathrm{~b}$ to $3 \mathrm{a}$ in St. Petersburg mediated by increase in injecting drug use. J. Med. Virol., 2001, vol. 65, pp. 517-524. doi: 10.1002/jmv.2066

8. Markov P.V., Pepin J., Frost E., Deslandes S., Labbe A.-C., Pybus O.G. Phylogeography and molecular epidemiology of hepatitis C virus genotype 2 in Africa. J. Gen. Virol., 2009, vol. 90, no. 9, pp. 2086-2096. doi: 10.1099/vir.0.011569-0

9. Messina J.P., Humphreys I., Flaxman A., Brown A., Cooke G.S., Pybus O.G., Barnes E. Global distribution and prevalence of hepatitis C virus genotypes. Hepatology, 2015, vol. 61, no. 1, pp. 77-87. doi: 10.1002/hep.27259

10. Mora N., Adams W.H., Kliethermes S., Dugas L., Balasubramanian N., Sandhu J., Nde H., Small C., Jose J., Scaglione S., Layden J.E. A Synthesis of Hepatitis C prevalence estimates in Sub-Saharan Africa: 2000-2013. BMC Infect. Dis., 2016, vol. 16, pp. 283. doi: 10.1186/s12879-016-1584-1

11. Mullis C.E., Laeyendecker O., Reynolds S.J., Ocama P., Quinn J., Boaz I., Gray R.H., Kirk G.D., Thomas D.L., Quinn T.C., Stabinski L. High frequency of false-positive hepatitis C virus enzyme-linked immunosorbent assay in Rakai, Uganda. Clin. Infect. Dis., 2013, vol. 57, no. 12, pp. 1747-1750. doi: 10.1093/cid/cit602

12. Njouom R., Frost E., Deslandes S., Mamadou-Yaya F., Labbé A.C., Pouillot R., Mbélesso P., Mbadingai S., Rousset D., Pépin J. Predominance of hepatitis $C$ virus genotype 4 infection and rapid transmission between 1935 and 1965 in the Central African Republic. J. Gen. Virol., 2009, vol. 90, no. 10, pp. 2452-2456. doi: 10.1099/vir.0.011981-0

13. Onakewhor J.U., Okonofua F.E. Seroprevalence of Hepatitis $\mathrm{C}$ viral antibodies in pregnancy in a tertiary health facility in Nigeria. Niger. J. Clin. Pract., 2009, vol. 12, no. 1, pp. 65-73.

14. Purdy M.A., Forbi J.C., Sue A., Layden J.E., Switzer W.M., Opare-Sem O.K., Phillips R.O., Khudyakov Y.E. A re-evaluation of the origin of hepatitis C virus genotype 2 in West Africa. J. Gen. Virol., 2015, vol. 96, no. 8, pp. 2157-2164. doi: 10.1099/ vir. 0.000153

15. Ruggieri A., Argentini C., Kouruma F., Chionne P., D’Ugo E., Spada E., Dettori S., Sabbatani S., Rapicetta M. Heterogeneity of hepatitis C virus genotype 2 variants in West Central Africa (Guinea Conakry). J. Gen. Virol., 1996, vol. 77, pp. $2073-2076$. doi: 10.1099/0022-1317-77-9-2073

16. Tagny C.T., Mbanya D., Murphy E.L., Lefrère J.J., Laperche S. Screening for hepatitis C virus infection in a high prevalence country by an antigen/antibody combination assay versus a rapid test. J. Virol. Methods, 2014, vol. 199, pp. 119-123. doi: 10.1016/ j.jviromet.2014.01.002

17. World Health Organization. Hepatitis C. WHO. Fact Sheet, April 2017.

\section{Авторы:}

Калинина О.В., д.б.н., ведущий научный сотрудник лаборатории молекулярной эпидемиологии и эволюционной генетики ФБУН НИИ эпидемиологии и микробиологии им. Пастера, Санкт-Петербург, Россия;

Личная Е.В., младший научный сотрудник лаборатории вирусных гепатитов ФБУН НИИ эпидемиологии и микробиологии им. Пастера, Санкт-Петербург, Россия; Буаро М.Й., профессор, директор НИИ прикладной биологии Гвинеи, г. Киндия, Гвинейская Республика;

Тотолян Арег А., академик РАН, д.м.н., профессор, зав. лабораторией молекулярной иммунологии, директор ФБУН НИИ эпидемиологии и микробиологии имени Пастера, Санкт-Петербург, Россия, Санкт-Петербург, Россия.

\author{
Authors: \\ Kalinina O.V., PhD, MD (Biology), Leading Researcher, Laboratory \\ of Molecular Evolution and Evolutionary Genetics, St. Petersburg \\ Pasteur Institute, St. Petersburg, Russian Federation; \\ Lichnaia E.V., Junior Researcher, Laboratory of Viral Hepatitis, \\ St. Petersburg Pasteur Institute, St. Petersburg, Russian Federation; \\ Boiro M.Y., Professor, General Director, Institute of Applied Biology \\ in Guinea, Kindia, Republic of Guinea; \\ Totolian Areg A., RAS Full Member, PhD, MD (Medicine), \\ Professor, Head of the Laboratory of Molecular Immunology, \\ Director of St. Petersburg Pasteur Institute, St. Petersburg, Russian \\ Federation.
}

